\title{
15
}

\section{Ainu Women in the Past and Now}

\author{
Ryoko Tahara (translated by Hiroshi Maruyama)
}

\section{Introduction}

Since the Meiji Restoration, we, the Ainu, have been dispossessed of our land, language and customs, for approximately 140 years, by Japan's invasion of Ainu land and subsequent assimilationist policies. Even now, the Ainu are subordinate to the majority Japanese in terms of education, economy and living standards, as a result of structural discrimination against the Ainu. In particular, Ainu women have found themselves subject to severe discrimination. Discrimination and suppression have led them into poverty, taken away their opportunities for education, impeded the development of their economic activities and hurt their pride as humans. These effects have been passed down through the generations. Infringement of human rights is mainly attributed to discrimination on the grounds of gender, ethnicity and so on. Gender and ethnic minority status combine to create special problems, that we Ainu women have come to recognise as double discrimination through our own learning activities. After becoming aware of our double discrimination we, the Ainu women, for the first time conducted a survey concerning the actual conditions of Ainu women. I will describe first, what discrimination Ainu women have experienced in the past and now, and second, what activities we have carried out in relation to the double discrimination we experience as minority women. 


\section{Ainu women in the past and now}

In general, the settlers and immigrants involved in the invasion and development of Indigenous peoples' land were mostly men. Indigenous women, therefore, have been targeted for men's sexual desires. The 1789 war of Menashi-Kunashir ${ }^{1}$ was directly triggered by the fact that two Ainu died unnaturally after eating their meals at a banya or workshop and lodging for fishermen. Against the backdrop of the war, the Ainu were forced to work for fisheries under daily threats and violence, and Ainu women were explicitly exposed to sexual violence by the Japanese merchants who ran the fisheries. ${ }^{2}$

The most brutal treatment of Ainu women was that they were kept as mistresses by Japanese bosses and immigrants, regardless of whether they were married or unmarried. If they resisted, their husbands were sometimes abused or even killed by the Japanese involved. After being raped by Japanese bosses, some Ainu women committed suicide by consuming a poisonous plant named torikabuto. ${ }^{3}$ A significant number of Japanese who kept Ainu women as their mistresses forced them to procure abortions if they became pregnant. Worse still, some Ainu women were infected with syphilis or smallpox by Japanese men. If such infections became known to the Japanese abuser, the Ainu woman was abandoned and left to her fate without even a bowl of rice or medicine. After death, her body was left to decay on a mountain in a make-shift shelter made from Japanese butterburs (petasites japonicus).

This situation, of Japanese looking down upon the Ainu and treating Ainu women as mistresses, lasted for several centuries. For example, some Japanese men, who had left their wives and children on the main island of Japan and worked as migrant workers in Hokkaidō, lived together with Ainu women there. After a year or so, those Japanese men would return to their homes, leaving the Ainu women and new-born babies of mixed parentage behind. When leaving Hokkaidō, they often made the Ainu women believe that they were going to look for a job or that they wanted

1 In May 1789, the Ainu rose up in rebellion against the cruel Japanese treatment of the Ainu. Events took place on the Shiretoko Peninsula in northeastern Hokkaidō. Seventy-one Ainu persons died at the hands of the Japanese. The Matsumae domain, which was endorsed by the Tokugawa Shogunate as the Lord of Hokkaidō, immediately suppressed the rebellion in cooperation with some Ainu leaders. Thirty-seven Ainu were charged with rebellion and beheaded.

2 Throughout this article, 'Japanese' implies ethnically Japanese.

3 Torikabuto is a poisonous plant and usually used as poison for hunting by the Ainu. 
to obtain their parents' consent to marry them. Such despicable behaviour by Japanese men against Ainu women came to an end just a few decades ago. Many Ainu women suffered from this sort of deception. However, other Ainu women intended to marry Japanese men so they would have half-Japanese and half-Ainu children. Their desire was that their children would not inherit the physical characteristics of the Ainu, so they would avoid discrimination.

Inferior living standards, destitution and the ideology of male dominance implanted by the Japanese all prevented Ainu women from gaining adequate education. As a result, there are still illiterate Ainu women. In our own survey of Ainu women for the UN (described below), nearly 30 per cent of the surveyed Ainu women found it difficult to read the Japanese language, and a third of them wrote Japanese characters with difficulty. They have no choice but to engage in physical labour or restaurant work; both of which provide unstable employment and pay low wages.

Cases in which Ainu women are refused marriage or close relationships with Japanese men because of their ethnicity are sometimes reported. These women attempt to hide their Ainu identity, disparage their parentage and suffer from mental agony. They also tend to choose underprivileged men for their husbands. These men sometimes inflict violence on them as a way of giving vent to their everyday frustrations. It is not uncommon for such couples to be unable to afford tuition and other expenses for their children's schooling. Thus the children too are caught in a vicious cycle of reproducing destitution.

\section{The idea of double discrimination in our hands}

As soon as we Ainu women started to understand that the term 'double discrimination' is applicable to the situations we face, we have been motivated to organise a campaign for the restoration of Ainu women's rights. The term 'double discrimination' encouraged us to entertain hopes that we could emancipate ourselves from discrimination. We began examining the idea and the structure of double discrimination by attending study meetings. We confirmed the situation facing us and talked with each other about our bitter experiences of discrimination. In tears, one 
Ainu woman, for the first time, laid bare her true feelings and experiences of discrimination. She did not want to let those experiences be known to others and to make her family feel sad by knowing about them. Those who feel ashamed are the Ainu women who were discriminated against, not the Japanese who discriminated against them. It is absurd, but a reality. Through attending just a few study meetings, we drastically changed our minds. In other words, we came to have the courage to see ourselves as we are by learning about the idea of double discrimination.

We brought the actual conditions of minority women, including Ainu women, to light through the above-mentioned survey. Further, we worked to improve our living conditions and to eliminate the discrimination against us. We wanted to help the authorities take measures and prepare regulations. Then, we turned our attention to the International Convention on the Elimination of All Forms of Discrimination against Women. From 30 June to 18 July 2003, the Committee on the Elimination of Discrimination against Women (CEDAW) held its 29th session to examine the country reports of state parties, including the fourth and fifth periodic reports of Japan, at the United Nations Headquarters in New York. We submitted our report on the actual conditions of Ainu women to CEDAW before the session. Also, we had an opportunity to attend the session. Additionally, we carried out lobbying and briefing for persons concerned.

In August 2003, the report on the 29th session came from the CEDAW. According to the report, the committee expressed concern on two points. One was the lack of information in the reports about the situation of minority women in Japan. Another was the multiple forms of discrimination and marginalisation that these groups of women may face with respect to education, employment, health, social welfare and exposure to violence, including within their own communities (CEDAW 2003: 135). Based on these concerns, the committee recommended the Government of Japan provide,

in its next report, comprehensive information, including disaggregated data, on the situation of minority women in Japan, especially with regard to their educational, employment and health status and exposure to violence (CEDAW 2003: 135-36). 
Thus, the sufferings and difficulties that Ainu women have faced for centuries finally came to light for the first time in history. We were convinced that we could change our fate if we could eradicate our resignation to discrimination.

From October 2004 to February 2005, we carried out a survey on the actual conditions of Ainu women for the first time in history. The motivation for the survey was that we wanted to know more about ourselves. Involvement in the survey gave the participants, including me, self-confidence. Those participants, who had once taken no notice of discrimination and human rights, gained the ability to see what constitutes double discrimination. The survey and associated activities functioned as therapies to heal our wounded pride, and encourage us to have hope for the future.

Before coming to recognise double discrimination, we, Ainu women, had difficulties in wording the variety of challenges faced by us. We cleared up these difficulties by learning and taking actions on our own. I would like to continue activities of this sort to raise questions faced by Ainu women. Also, I hope Ainu women, who worked with me on the survey, will be actively involved in a variety of fields to end discrimination. Further, I was impressed by the fact that an illiterate Ainu woman was pleased to be able to read a signboard with 'TOYOTA' written in Roman letters on the street, after learning Roman letters along with the Ainu language. It is not easy for Ainu women, who have had no chance to learn Japanese grammar and Roman letters, to learn the Ainu language. Japan's colonisation of Ainu land is still punishing Ainu women. Learning culture, however, sometimes makes these marginalised persons confident in their identity as Ainu. Recognition of double discrimination and learning Ainu culture go hand in hand with each other for the decolonisation of Ainu women.

\section{References}

Ainu Association of Hokkaidō (Sapporo Branch). 2007. Research Project for Double Discrimination against Minority Women, including Ainu Women, Ukopararui. Sapporo. 
Committee on the Elimination of Discrimination against Women (CEDAW). 2003. Report of the Committee on the Elimination of Discrimination against Women, General Assembly, Official records, Fifth-eighth session, Supplement No. 38 (A/58/38). Online: tbinternet.ohchr.org/_layouts/treaty bodyexternal/Download.aspx?symbolno=A $\% 2 f 58 \% 2 f 38$ (SUPP) \&Lang=en (accessed 15 July 2018). 
This text is taken from Indigenous Efflorescence: Beyond Revitalisation in Sapmi and Ainu Mosir, edited by Gerald Roche, Hiroshi Maruyama and Åsa Virdi Kroik, published 2018 by ANU Press, The Australian National University, Canberra, Australia.

doi.org/10.22459/IE.2018.15 